\title{
KLF5 wt Allele
}

National Cancer Institute

\section{Source}

National Cancer Institute. KLF5 wt Allele. NCI Thesaurus. Code C102502.

Human KLF5 wild-type allele is located in the vicinity of $13 q 22.1$ and is approximately 23 $\mathrm{kb}$ in length. This allele, which encodes Krueppel-like factor 5 protein, is involved in the regulation of transcription. 